\title{
Pengikatan Jaminan Kebendaan dalam Kontrak Pembiayaan Mudāarabah Sebagai Upaya Penyelesaian Sengketa Debitur Wanprestasi (Analisis Putusan MA Nomor 272/K/AG/2015 Tentang Pembiayaan Muḍārabah)
}

\author{
Mhd. Yadi Harahap \\ Fakultas Syariah dan Hukum Universitas Islam Negeri Sumatera Utara \\ Jl. William Iskandar Ps. V Medan Estate, Deli Serdang Sumatera Utara 20371 \\ E-mail:mhdyadiharahap@uinsu.ac.id
}

\begin{tabular}{llll} 
Submit & $: 22$ Agustus 2019 & Diterima & $:$ 18 Mei 2020 \\
Revisi & $: 02$ Oktober 2019 & Terbit & $:$ 03 Juni 2020 \\
\hline
\end{tabular}

\begin{abstract}
Abstrak: Pembebanan jaminan dalam kontrak pembiayaan mudārabah merupakan permasalahan tersendiri pada bank syariah sekalipun pada prinsipnya bank syariah tidak wajib meminta jaminan. Namun dalam penerapannya jaminan merupakan salah satu unsur yang harus dipenuhi oleh pelaku usaha dalam kontrak pembiayaan mudārabah. Ketika pembebanan jaminan tidak diterapkan sering kali muncul permasalahan dalam hal debitur wanprestasi. Permasalahan dalam penelitian ini adalah apakah pembebanan jaminan dapat dijadikan sebagai upaya penyelesaian sengketa debitur wanprestasi dalam kontrak pembiayaan mudārabah. Untuk menjawab pertanyaan penelitian tersebut metode yang digunakan adalah metode penelitian yuridis normatif di mana hukum tidak hanya dilihat sebagai law in books tetapi juga law in action dengan pendekatan peraturan perundangundangan dan pendekatan studi kasus yaitu putusan Mahkamah Agung. Sehingga ditemukan jawaban secara komprehensif tentang pembebanan jaminan dalam kontrak pembiayaan muḍärabah sebagai solusi penyelesaian sengketa debitur wanprestaasi. Hasil penelitian mempresentasikan bahwa pengikatan jaminan dalam kontrak pembiayaan mudārabah dapat dijadikan sebagai antisipasi untuk memanimalisasi risiko kerugian berdasarkan pasal 39 UU No. 21 Tahun 2008 Tentang Perbankan Syariah. Ketika pelaku usaha wanprestasi, lalai dan menyalahi kontrak dalam pembaiayaan mud̄ārabah maka jaminan dapat dijadikan sebagai upaya mitigasi penyelesaian sengketa pembiayaan mud̄ārabah untuk melunasi kewajibannya kepada bank syariah.
\end{abstract}

Kata Kunci: Jaminan, muḍāabah, debitur, wanprestasi, penyelesaian sengketa

Abstract: The imposition of collateral in mudārabah financing contracts is a separate issue for Islamic banks even though in principle Islamic banks are not required to ask for collateral, but in practice collateral is one of the elements that must be met by business actors in mudārabah financing contracts. When the collateral is not applied, problems often arise in the case of debtor default. The problem in this study is whether the imposition of collateral can be used as an effort to resolve debtor disputes in mudärabah financing contracts. To answer the research question, the method used is a normative juridical research method where the law is not only seen as law in books but also law in action with the statutory approach and case study approach, namely the decision of the Mahkamah Agung. The results of the study presented that binding guarantees in mudārabah financing contracts can be used as an anticipation to minimize the risk of loss based on article 39 of Law no. 21 of 2008 concerning Islamic Banking. When the business actor defaults, neglects and breaches the contract in mud̄arabah financing, the guarantee can be used as an effort to mitigate the settlement of mudārabah financing disputes to pay off obligations to Islamic banks.

Keywords: collateral, mud̄ārabah, debtors, defaults, dispute. 


\section{Pendahuluan}

Pembebanan jaminan dalam kontrak pembiayaan muḍārabah dimaksudkan sebagai penyerahan kekayaan atau pernyataan kesanggupan mudārib untuk menanggung pembayaran kembali modal yang diberikan. Menurut Pasal 1 Undang-undang No. 21 Tahun 2008 Tentang perbankan syariah, jaminan yang dimaksud adalah jaminan tambahan, baik berupa benda bergerak maupun benda tidak bergerak yang diserahkan oleh pemilik agunan kepada Bank Syariah dan/ atau UUS, guna menjamin pelunasan kewajiban nasabah penerima fasilitas. ${ }^{1}$ Hal yang sama juga diintroduksi pasal 1 Undangundang No. 10 Tahun 1998 Tentang Perbankan bahwa agunan adalah jaminan tambahan yang diserahkan nasabah debitur kepada bank dalam rangka pemberian fasilitas kredit atau pembiayaan berdasarkan prinsip syariah. ${ }^{2}$

Penjelasan kedua undang-undang di atas terdapat dua jenis jaminan, yaitu jaminan pokok dan jaminan tambahan berupa benda berwujud yang bernilai ekonomis untuk digunakan sebagai pelunasan pembiayaan berdasarkan prinsip syariah jika nasabah wanprestasi. Jaminan pokok dapat berupa barang, surat berharga, atau garansi yang berkaitan langsung dengan objek yang dibiayai dengan pembiayaan yang bersangkutan, seperti barang-barang yang dibeli dengan angsuran yang dijaminkan, proyek yang dibiayai dengan pembiayaan yang bersangkutan yang dijadikan sebagai jaminan. Sedangkan jaminan tambahan adalah berupa barang, surat berharga atau garansi yang tidak berkaitan langsung dengan objek yang dibiayai dengan kredit atau pembiayaan yang bersangkutan yang ditambahkan sebagai jaminan..$^{34}$

Legalitas pengaturan hukum jaminan di Indonesia diatur di dalam berbagai peraturan perundangundangan yaitu hak tanggungan diatur dalam UU No. 4 Tahun 1996, jaminan fidusia diatur dalam UU No. 42 tahun 1999, gadai dan hipotek diatur dalam KUHPerdata dan jaminan dalam bentuk rahn dan kafälah diatur dalam bentuk fatwa DSN-MUI dan Perataruan Mahkamah Agung No. 08 Tahun 2008. ${ }^{5}$ Bank syariah menentukan bahwa peraturan tentang pembebanan dan pengikatan jaminan mengacu kepada sistem hukum nasional, artinya jika objek jaminan tersebut benda bergerak maka mengacu kepada undang-undang jaminan fidusia dan jika objek jaminan tersebut benda tidak bergerak khususnya berkaitan dengan tanah dan bangunan yang berada di atasnya maka mengacu kepada undang-undang hak tanggungan. Hal ini telah diterapkan dalam kontrak pembiayaan mudārabah pada bank syariah sepanjang belum ada ketentuan khusus yang mengatur tentang jaminan syariah yang berlaku dan diterapkan pada bank syariah.

Undang-undang No. 10 Tahun 1998 tentang Perbankan dan Undang-undang No. 21 Tahun 2008 tentang Perbankan Syariah memaknai istilah jaminan sebagai keyakinan atas iktikad dan kemampuan serta kesanggupan nasabah debitur untuk melunasi utangnya atau mengembalikan pembiayaan dimaksud sesuai dengan yang diperjanjikan. ${ }^{6}$ Penerapannya pada bank syariah keyakinan dan

\footnotetext{
"Undang-Undang Nomor 21 Tahun 2008 Tentang Perbankan Syariah" (2008).

“Undang-Undang Nomor 10 Tahun 1998 Tentang Perbankan” (1998).

Djawahir Hejazziey, Hukum Perbankan Syariah (Yogyakarta: Deepublish, 2013), 163.

Djawahir hejazziey, Hukum Perbankan Syariah, Cetakan Pertama, (Yogyakarta: Deepublish, 2013), 163.

Lebih lanjut pengaturan hukum jaminan di Indonesia diatur dalam berbagai Fatwa Dewan Syariah Nasional Majelis Ulama Indonesia (DSN-MUI) dan Peraturan Mahkamah Nomor 08 Tahun 2008 Tentang Kompilasi Hukum Ekonomi Syariah. Jaminan disitilahkan dengan rahn dan kafälah. Sedangkan jaminan dalam bentuk lain diatur melalui Undang-undang Nomor 4 Tahun 1996 tentang Hak Tanggungan, Undang-undang Nomor 42 Tahun 1999 Tentang Jaminan Fidusia, dan gadai dalam Kitab Undang-undang hukum Perdata BW.

6 Penjelasan ini dapat dilihat pada pasal 23 Undang-undang nomor 21 Tahun 2008 Tentang Perbankan Syariah dan pasal 8 Undang-undang Nomor 10 Tahun 1998 Tentang perbankan. Ketika pemberian kredit atau pembiayaan berdasarkan Prinsip
} 
iktikad baik dari mudāarib disertasi dengan benda berwujud yang bernilai ekonomis yang dijadikan sebagai perlindungan atau antisipasi jika pembiayaan yang diberikan gagal bayar oleh karena mudārib melakukan moral hazard. ${ }^{7}$ Untuk pengikatan jaminan yang diberikan oleh muḍāib kepada bank syariah harus dibuat dalam bentuk perjanjian yang disebut dengan perjanjian pengikatan jaminan. Perlu di pahami bahwa pengikatan jaminan yang dimaksud merupakan jaminan tambahan dan merupakan perjanjian accessoir. ${ }^{8}$

Kesemua lembaga jaminan yang ada di indonesia yaitu jaminan perorangan yang terdiri dari personal guaranty (penaggung adalah orang perorangan) dan corporate guaranty (penanggung adalah berbentuk perusahaan). Jaminan perorangan di atur dalam pasal 1820-1850 BW, terdiri dari personal guaranty dan corporate guaranty. Personal guaranty yang ditunjuk sebagai penjamian atau penanggung adalah orang perorangan sedangkan corporate guaranty penjaminan yang ditunjuk berbentuk perusahaan. ${ }^{9}$ Sedangkan jaminan kebendaan terdiri dari gadai, hak tanggungan, dan fidusia. Untuk jaminan perorangan yang sering diistilahakn dengan borgtocht merupakan perjanjian penanggungan di mana seorang pihak ketiga menanggung dan mengikatkan diri untuk kepentingan si berpiutang (kreditur) untuk memenuhi perjanjian si berutang (debitur) manakala debitur wanprestasi. ${ }^{10}$

Untuk jaminan perorangan, borg akan menjamin kewajiban debitur dengan seluruh harta borg, dan untukjaminan kebendaan selalu ada benda tertentu secara khusus ditunjuk oleh undang-undang dengan tujuan memberikan jaminan untuk dipenuhi kewajiban debitur dalam perjanjian pokok. Keseluruhan jaminan yang diterapkan dalam kontrak pembiayaan mud̄ārabah pada bank syariah, apakah jaminan kebendaan atau jaminan perorangan bersifat accessoir, artinya selalu dikaitkan dengan perjanjian pokok yaitu: tidak ada jaminan tambahan dan penanggungan tanpa didahului jaminan pokok, besarnya jaminan pokok tidak melebihi jaminan tambahan, jaminan tambahan dan penanggungan pada umumnya akan hapus ketika hapus jaminan pokok. ${ }^{11}$ Tujuan pembebanan dan pengiktan jaminan, apakah jaminan kebendaan atau perorangan yang diberikan debitur kepada bank untuk meyakinkan bank bahwa apabila debitur tidak mampu mengembalikan hutang, barangbarang tersebut dapat dicairkan untuk melunasi utang debitur. ${ }^{12}$

Syariah, Bank Umum wajib mempunyai keyakinan berdasarkan analisis yang mendalam atas itikad dan kemampuan serta kesanggupan nasabah debitur untuk melunasi utangnya atau mengembalikan pembiayaan dimaksud sesuai dengan yang diperjanjikan.

Jaminan yang dimaksud adalah barang, proyek atau hak tagih yang dibiayai dengan fasilitas Pembiayaan yang bersangkutan dan barang lain, surat berharga atau garansi risiko yang ditambahkan sebagai Agunan tambahan apakah sudah cukup memadai, sehingga apabila Nasabah Penerima Fasilitas kelak tidak dapat melunasi kewajibannya, Agunan tersebut dapat digunakan untuk menanggung pembayaran kembali Pembiayaan dari Bank Syariah dan/atau UUS yang bersangkutan. Penjelasan Pasal 23 Undang-undang Nomor 21 Tahun 2008 Tentang perbankan Syariah, Undang-undang Nomor 21 Tahun 2008 Tentang Perbankan Syariah.

8 Untuk pengikatan jaminan fidusia dilakukan dalam bentuk tertulis atau akta Notaris dan tidak perlu dilakukan penyerahan yang menjadi objek jaminan fidusia secara fisik sesuai dengan pasal 5 Undang-undang Nomor 42 Tahun 1999 Tentang Jaminan Fidusia yang disebut dengan perjanjian jaminan fidusia. Untuk pengikatan jaminan hak tanggungan dapat dilihat dalam pasal 10,11, dan 12 Undang-undang Nomor 4 Tahun 1996 Tentang Hak Tanggungan Atas Tanah Beserta Benda-benda yang Berkaiyan dengan tanah.

9 Penanggungan adalah suatu perjanjian di mana pihak ketiga, guna kepentingan si berutang mengikatkan diri untuk memenuhi perutangan manakal si berutang itu wanporestasi. Pasal 1820 BW. Ny. Hj. Frieda Husni Hasbullah, Hukum Kebendaan Perdata : Hak-Hak Yang Memberi Jaminan (Jakarta: Ind.Hill Co, 2002), 12.

10 Sri Soedewi Masjchoen Sofwan, Hukum Jaminan Di Indonesia, Pokok-Pokok Hukum Jaminan Dan Jaminan Perorangan (Yogyakarta: Liberty, 1980), 38.

11 J Satrio, Hukum Jaminan, Hak-HakJaminan Pribadi Penanggungan (Borgtocht) Dan Perikatan Tanggung - Menanggung (Bandung: Cipta Aditya Bakti, 1996), 5-6.

12 Nina Kurnia Dewi Nasroen Yasabri, Penjaminan Kredit: Mengantar UKMK Mengakses Pembiayaan (Bandung: Alumni, 2008$), 13$. 
Uraian mengenai hukum jaminan yang bermuara dari ketentuan umum pasal 1 ayat (26) dan pasal 23 ayat (1) dan (2), memberikan suatu konklusi bahwa pada dasarnya dalam hubungan pemberian pembiayaan perbankan syariah terutama pembiayaan mudārabah senantiasa ada jaminan, yaitu kekayaan mudārib yang bersangkutan. ${ }^{13}$ Secara hukum hampir tidak akan mungkin terjadi pemberian pembiayaan mudāarabah tanpa jaminan, termasuk praktik perbankan syariah yang sering menggunakan unsecured money market line atau unsecuret loan. Pemberian pembiayaan mudāarabah secara hukum harus dipahami sebagai pembiayaan yang tidak dijamin dengan harta mud̄ārib yang ditujuk secara khusus, melainkan jaminan yang paling utama adalah keyakinan dan usaha muḍārib yang dibiayai oleh perbankan syariah. ${ }^{14}$ Ketika pembebanan jaminan tidak diterapkan maka akan muncul permasalahan dalam hal debitur wanprestasi, bagaimana mekanisme pembayaran pembiayaan yang diberikan oleh bank syariah. Selain itu apa yang menjadi dasar pemikiran hukum tentang fungsi dan tujuan pembebanan jaminan dalam montrak pembiayaan mudärabah. Apakah pembebanan jaminan dapat dijadikan sebagai upaya memperkecil penyelesaian sengketa pembiayaan muḍārabah dalam hal debitur wanprestasi.

Salah satu kasus yang menarik untuk diteliti adalah putusan Mahkamah Agung tentang pembiayaan mudārabah dengan pembebanan jaminan. Hal yang menarik adalah dalam hal debitur wanprestasi apakah bank syariah dapat memindahalihkan objek jaminan dalam kontrak pembiayaan mudārabah di mana secara kontektualitas fikih tidak dibenarkan adanya jaminan. Untuk menjawab pertanyaan penelitian di atas, penulis menggunakan metode penelitian yuridis normatif atau penelitian hukum doktrinal dengan pendekatan studi kasus dengan tujuan untuk menemukan jawaban secara komprehensif dan holistik. Sehingga ditemukan kebenaran dan kebaharuan dari sudut norma hukum, apakah norma hukum, azaz hukum, kaidah hukum yang ada dapat menyelesaikan permasalahan hukum. Pendekatan studi kasus digunakan karena penelitian ini memfokuskan pada kajian terhadap putusan Mahkamah Agung Nomor 272/K/AG/2015 Tentang Penyelesaian Sengketa Pembiayaan Mudārabah. Pendekatan studi kasus dimungkinakan ditemukan efektivitas hukum. Kedua pendekatan ini diyakini dapat menjawab dan menganalisis terhadap permasalahan yang berbasis pada analisis asas-asas dan norma hukum yang tertulis di dalam peraturan perundang-undangan, khususnya UU No. 21 Tahun 2008 Tentang Perbankan Syariah.

\section{Posisi Kasus Putusan MA Nomor 272/K/AG/2015 tentang Pembiayaan Muḍārabah}

Pembebanan jaminan dalam kontrak pembiayaan mudārabah di Indonesia merupakan salah satu bentuk antisipasi ketika mudārib melakukan wanprestasi atau default akibat kesalahan yang disengaja. Ada beberapa kasus yang ditemukan penulis terkait jaminan yang dapat dijadikan sebagai mitigasi dari character risk dari muḍārib pada kontrak pembiayaan mudārabah ketika mud̄ārib wanprestasi. Salah satu dari kasus tersebut adalah terkait penyelesaian sengketa kontrak pembiayaan mudārabah dengan pembebanan jaminan. Kasus berikut ini merupakan salah satu contoh bahwa pembeban

\footnotetext{
13 Agunan yang dimaksud adalah jaminan tambahan, baik berupa benda bergerak maupun benda tidak bergerak yang diserahkan oleh pemilik agunan kepada Bank Syariah dan/atau UUS, guna menjamin [elunasan kewajiban nasabah penerima fasilitas. Suyatno salah satu ahli perbankan berpendapat bahwa jaminan dimaksud adalah penyerahan kekayaan atau pernyataan kesanggupan seseorang untuk menanggung pembayaran kembali suatu utang. Thomas Suyatno, Dasar-Dasar Perkreditan (Jakarta: Gramedia, 1988), 70.

14 Penjelasan lebih lanjut dapat dilihat pada pasal 23 ayat (1-2) dan penjelasannya Undang-undang Nomor 21 Tahun 2008 Tentang Perbankan Syariah.
} 
jaminan dalam kontrak pembiayaan mud̄ārabah merupakan bentuk mitigasi dari character risk dari mud̄ārib bukan merupakan mengantisipasi risiko kerugian (busines risk). Putusan Mahkamah Agung Nomor 272/K/AG/2015 tentang kasus penyelesaian sengketa pembiayaan mud̄ārabah muqayyadah. Kasus ini terjadi antara PT. Permodalan BMT Ventura, beralamat di Equity Tower 27 th Floors, Komplek SCBD, Jl. Jend. Sudirman Kav 52-53, Jakarta, dalam hal ini sebagai penggugat. Melawan Toto Saptori, beralamat di Jl. Sudirman, Rt.002, Rw.001, Kelurahan Bantarujeg, Kecamatan Bantarujeg, Kabupaten Majalengka, Jawa Barat. Bahwa penggugat telah mengajukan gugatan mud̄àrabah terhadap termohon kasasi dan para turut termohon kasasi dahulu sebagai para tergugat di muka persidangan Pengadilan Agama Jakarta Selatan. ${ }^{15}$

Sekitar tahun 2010, penggugat dalam hal ini PT Permodalan BMT Ventura memberikan dua kali Fasilitas Pembiayaan untuk keperluan modal kerja kepada tergugat I sebesar total Rp. 1.800.000.000,00 (satu miliar delapan ratus juta rupiah) dengan jaminan berupa: (1) Sertipikat Hak Milik No. 0060 atas nama Dadi Mulyadi atas tanah yang terletak di Desa Gandu, Kec. Dawuan, Majalengka yang telah diberikan oleh tergugat. (2) Personal guarantee (jaminan pribadi) atas nama Nana Suryana. ${ }^{16}$ Pada tanggal 1 Mei 2010 penggugat dan tergugat menyepakati membuat dan menandatangani akad pembiayaan mud̄ārabah muqayyadah No.081/ mud̄ārabah muqayyadah/PBMT/V/2010 selanjutnya disebut sebagai "perjanjian fasilitas pembiayaan mudārabah muqayyadah", di mana tergugat telah menerima dan menggunakan fasilitas pembiayaan tanggal yang disediakan oleh penggugat untuk keperluan modal kerja tergugat dengan jumlah total sebesar Rp. 800.000.000,00 (delapan ratus juta rupiah), dengan jangka waktu pengembalian selama 2 (dua) tahun terhitung dari bulan Mei $2010 \mathrm{~s} / \mathrm{d}$ Mei 2012. ${ }^{17}$

Kemudian tergugat mengajukan permohonan penambahan fasilitas pembiayaan kepada penggugat untuk kedua kalinya dan kemudian pembiayaan tersebut dituangkan dalam akad pembiayaan mudārabah muqayyadah No. 081tanggal 3 Juli 2010 yang merupakan satu kesatuan dan tidak terpisahkan dengan perjanjian fasilitas pembiayaan $1 \mathrm{Mei}$ di atas, dengan nilai pokok pembiayaan sejumlah Rp. 1.000.000.000,00 (satu miliar rupiah), dengan jangka waktu pengembalian selama 2 (dua) tahun terhitung dari bulan Juli 2010 s/d Juli 201. Berdasarkan tanda bukti transfer dari penggugat kepada tergugat, telah terbukti atas perjanjian fasilitas pembiayaan 1 Mei 2010 dan perjanjian fasilitas pembiayaan 3 Juli 2010, Penggugat telah mentransfer masing-masing sebesar Rp. 800.000.000,00 (delapan ratus ratus juta rupiah) pada tanggal 5 Mei 2010, telah diterima sepenuhnya oleh tergugat. ${ }^{18}$

Akibat dari kontrak pembiayaan mud̄ärabah yang disepakati kedua belah pihak, maka tergugat mempunyai kewajiban kepada penggugat untuk membayar pokok pembiayaan beserta nisbah selama jangka waktu pembiayaan dan hal itu merupakan kewajiban dari tergugat kepada penggugat. Fasilitas

15 Direktori Putusan Mahkamah Agung Republik Indonesia. Admin, “Direktori Putusan - Mahkamah Agung," n.d., https:// putusan3.mahkamahagung.go.id/.

16 Pasal 1820 KUHPerdata: Penanggungan adalah suatu perjanjian dengan mana seorang pihak ketiga, guna kepentingan si berpiutang, mengikatkan diri untuk memenuhi perikatan si berpiutang manakala orang itu sendiri tidak memenuhinya. Pasal 1367 KUHPerdata: Seorang tidak saja bertanggung jawab untuk kerugian yang disebabkan perbuatannya sendiri, tetapi juga untuk kerugian yang disebabkan perbuatan orang-orang yang menjadi tanggungannya atau disebabkan oleh barang-barang yang berada di bawah pengawasannya.

17 Hasil Putusan Mahkamah Agung Republik Indonesia Nomor 272/K/AG/2015 Tentang Kasus Penyelesaian Sengketa Pembiayaan Mudāāabah Muqayyadah. Putusan ini ditetapkan pada hari Rabu Tanggal 29 April 2015.

18 Disadur dari Putusan Mahkamah Agung Republik Indonesia, Putusan Mahkamah Agung Nomor 272/K/AG/2015 tentang kasus penyelesaian sengketa pembiayaan mud̦ärabah muqayyadah. 
pembiayaan yang telah diberikan oleh penggugat kepada tergugat seharusnya dapat menjadi modal kerja dan dapat dipergunakan untuk memperluas kegiatan usahanya, namun kemudian fasilitas pembiayaan tersebut tidak digunakan sesuai dengan peruntukannya yang mengakibatkan tergugat tidak membayar kewajibannya kepada penggugat. ${ }^{19}$ Tindakan tergugat yang tidak memenuhi kewajibannya bertentangan dengan doktrin yaitu wanprestasi di mana dalam hal ini tidak memenuhi atau lalai melaksanakan kewajiban sebagaimana yang ditentukan dalam perjanjian ${ }^{20}$ atau debitur melaksanakan sesuatu yang tidak diperbolehkan. ${ }^{21}$

Menurut Subekti seseorang dikatakan wanprestasi atau lalai yaitu jika ia tidak memenuhi kewajiban atau terlambat memenuhinya, atau memenuhinya tetapi tidak seperti yang telah diperjanjikan". Ketika seseorang telah melakukan wanprestasi, maka ia dapat dituntut dimuka hakim sebagai berikut: Pertama, debitur diminta untuk melaksanakan isi perjanjian, meskipun isi pelaksanaan ini sudah terlambat. Kedua, debitur diminta mengganti kerugian saja yaitu kerugian yang diderita kreditur karena perjanjian tidak atau terlambat dilaksanakan atau dilaksanakan tetapi tidak sebagaimana mestinya. Ketiga, Kreditur menuntut pelaksanaan perjanjian disertai penggantian kerugian sebagai akibat terlambatnya pelaksanaan perjanjian. Keempat, apabila suatu perjanjian yang meletakkan kewajiban timbal balik, kelalaian satu pihak memberikan hak kepada pihak lain, maka pihak yang dirugikan dapat meminta perjanjian dibatalkan disertai penggantian kerugian. ${ }^{22}$

Berdasarkan faktor kesengajaan dan kelalaian yang dilakukan tergugat berdasarkan Pasal 1131 Pasal 1236 dan Pasal 1239 KUHPerdata, maka seluruh aset-aset tergugat baik bergerak berwujud dan tidak berwujud maupun tidak bergerak, baik yang telah dimiliki atau yang akan dimiliki dimasa mendatang menjadi jaminan atas seluruh kewajibannya kepada penggugat selain denda atau ganti rugi. ${ }^{23}$ Posisi kasus putusan Mahkamah Agung bahwa pemilik modal dalam hal ini sebagai penggugat telah mengirimkan somasi sampai tiga kali kepada tergugat sebagai upaya untuk menyelesaikan

\footnotetext{
19 Pembiayaan yang dimaksud adalah pembiayaan dalam bentuk kontrak mudārabah muqayyadah. Adapun Pembiayaan mud̄ārabah yang dapat diaplikasikan pada bank syariah dapat dalam bentuk mud̦ārabah muțlaqah dan muḍārabah muqayyadah. Secara umum berdasarkan kewenangan pemilik modal kontrak pembiayaan mudārabah pada perbankan syariah dapat dikategorikan dalam dua bentuk yaitu mudārabah muțlaqah dan mud̄ārabah muqayyadah. Muḍārabah muțlaqah merupakan akad perjanjian antara dua pihak yaitu șāhib al-maal dan mudharib di mana șāhib al-maal menyerahkan sepenuhnya atas dana yang diinvestasikan kepada mudharib untuk mengelola usahanya sesuai dengan prinsip syariah. Șāhib al-maal tidak memberikan batasan jenis usaha, waktu yang diperlukan, strategi pemasarannya, dan wilayah bisnis yang dilakukan, șāhib al-maal memberikan kewenangan yang sangat luas dan tidak dibatasi oleh spesifikasi jenis uasaha kepada mudharib untuk melaksanakan aktivitas usahanya sesuai dengn prinsip syariah. Sedangkan mudāarabah muqayyadah kebalikan dari mudārabah muțlaqah yaitu akad kerja sama usaha antara dua pihak, di mana pihak pertama sebagai pemilik dana dan pihak kedua sebagai pengelola dana. Pemilik dana menginvestsikan dananya kepada mudharib dan memberi batasan atas penggunaan dana yang diinvestasikan seperti batasan tempat dan tata cara berinvestasi, jenis investasi, objek investasi dan jangka waktu investasi. Adanya pembatasan ini seringkali mencerminkan kecendrungan umum șāhib al-maal dalam memasuki jenis usaha Pada prinsipnya akad muḍārabah sifatnya mutlak, yaitu pemilik modal tidak boleh menetapkan syarat tertentu kepada mudharib (mudāärabah muțlaqah ). Namun jika dipandang perlu, maka șāhib al-maal boleh menetapkan batasan-batasan dan syarat tertentu dengan tujuan untuk menghindari dan menyelamatkan modal dari risiko kerugian (mudāabah muqayyadah). Jeni Susyanti, Pengelola Lembaga Keuangan Syariah (Pekabbaru: Empat Dua, 2016), 18.

20 Salim H.S., Hukum Kontrak: Teori Dan Teknik Penyusunan Kontrak (Jakarta: Sinar Grafika, 2006), 98.

${ }_{21}$ Gunawan Wijaja, Seri Hukum Bisnis Memahami Prinsip Keterbukaan Dalam Hukum Perdata (Jakarta: Rajawali Press, 2006$), 357$.

22 Subekti, Pokok-Pokok Hukum Perdata (Jakarta: Intermasa, 2005), 147-148.

${ }_{23}$ Pasal 1131 KUHPerdata: "Segala kebendaan si berutang, baik yang bergerak maupun yang tak bergerak, baik yang sudah ada maupun yang baru akan ada dikemudian hari, menjadi tanggungan untuk segala perikatannya. Pasal 1236 KUHPerdata: "Si berutang adalah wajib memberikan ganti biaya, rugi dan bunga kepada si berpiutang, apabila ia telah membawa dirinya dalam keadaan tak mampu untuk menyerahkan kebendaannya, atau telah tidak merawat sepatutnya guna menyelamatkannya". Pasal 1239 KUHPerdata: “Tiap-tiap perikatan untuk berbuat sesuatu atau untuk tidak berbuat sesuatu, apabila si berutang tidak memenuhi kewajibannya, mendapatkan penyelesaiannya dalam kewajiban memberikan penggantian biaya, rugi dan bunga". Subekti, Kitab Undang-Undang Hukum Perdata (Jakarta: Pradnya Paramita, 2006), 127.
} 
kewajibannya atas dua fasilitas pembiayaan yang telah diterimanya. Jumlah kewajiban yang belum dibayarkan kepada penggugat pertanggal 23 Desember 2011 adalah sebesar Rp. 848.981.589,60 (delapan ratus empat puluh delapan juta Sembilan ratus delapan puluh satu ribu lima ratus delapan puluh sembilan koma enam puluh rupiah). Tindakan pelaku usaha dalam hal ini tergugat telah wanprestasi atau default sebagaimana dimaksud dalam Pasal 1238 KUHPerdata. Tergugat yang tidak melaksanakan kewajibannya jelas-jelas telah wanprestasi dan melanggar hak-hak penggugat sesuai dengan kesepakatan yang tertuang dalam perjanjian fasilitas pembiayaan 1 Mei 2010 dan perjanjian fasilitas pembiayaan 3 Juli 2010. ${ }^{24}$

Akibat tindakan wanprestasi yang dilakukan oleh tergugat dengan tidak membayar kewajibannya atas fasilitas pembiayaan yang telah diterimanya mengakibatkan kerugian penggugat dengan rincian sebagai berikut (terhitung per April 2012): Jumlah keseluruhan kewajiban pokok, hasil, dan denda Total Rp.1.526.846.507.91. Jumlah tersebut akan terus bertambah jika para tergugat tidak segera membayarnya kepada penggugat. Penggugat pada tanggal 2 Agustus 2011 telah mengirimkan surat somasi 1 kepada tergugat yang pada pokoknya penggugat memberitahukan tergugat atas fasilitas pembiayaan yang telah diterimanya. Kemudian penggugat telah mengirimkan somasi ke 2 tertanggal 23 Desember 2011 kepada tergugat yang pada pokoknya penggugat meminta tergugat untuk menyelesaikan kewajibannya atas) fasilitas pembiayaan yang telah diterimanya, dengan jumlah kewajiban yang belum dibayarkan kepada penggugat tanggal 23 Desember 2011 terakhir penggugat mengirimkan somasi ke 3 tertanggal 5 Maret 2012 kepada tergugat. ${ }^{25}$ Merujuk pada kejadian tersebut dan dikhawatirkan tergugat akan mengalihkan atau memindahkan harta asset miliknya, serta tindakan-tindakan lain yang dapat merugikan penggugat, maka penggugat memohon agar Majelis Hakim Pengadilan Agama Jakarta Selatan agar berkenan untuk segera meletakkan sita jaminan terhadap seluruh harta kekayaan milik tergugat berupa barang bergerak, baik barang bergerak, serta barang tidak bergerak yang dimilikinya sesuai dengan perjanjian. Hal tersebut menunjukkan bahwa pada prinsipnya pembebanan jaminan dapat dijadikan sebagai upaya debitur wanprestasi. ${ }^{26}$

Pengadilan Agama Jakarta Selatan menyatakan dalam putusannya: (1). Mengabulkan gugatan penggugat untuk seluruhnya. (2). Menyatakan akad pembiayaan mud̄ārabah muqayyadah tanggal 1 Mei 2010 yang dilegalisasi oleh Notaris yang dibuat dan ditandatangani oleh penggugat dan tergugat adalah sah secara hukum. (3). Menyatakan tergugat wanprestasi terhadap akad pembiayaan mudāarabah muqayyadah no. 081 tanggal 1 mei. (4). Menghukum tergugat untuk membayar kepada penggugat uang sebesar Rp1.526.846.507.91 ditambah dengan bagi hasil perbulan terhitung sejak didaftarkannya gugatan ini. (5). Menyatakan bahwa sita jaminan yang telah dijalankan terhadap harta harta kekayaan tergugat adalah sah dan berharga. Menyatakan bahwa putusan dalam perkara

\footnotetext{
24 Pasal 1238 KUHPerdata menyebutkan Si berutang adalah lalai, apabila ia dengan surat perintah atau dengan sebuah akta sejenis itu telah dinyatakan lalai, atau demi perikatannya sendiri, ialah jika ini menetapkan, bahwa si berutang harus dianggap lalai dengan lewatnya waktu yang ditentukan.

25 “Putusan Mahkamah Agung Nomor 272/K/AG/2015 Tentang Pembiayaan Mudārabah," 2015.

${ }^{26}$ Harta yang dimaksud antara lain: Sebidang tanah dan bangunan milik tergugat I yang terletak di Jl. Jend. A. Yani No. 15, Bantarujeg Kab. Majalengka, Jawa Barat. Sebidang tanah dan bangunan milik tergugat II yang terletak di Jl. Sudirman No. 90, Rt. 001, Rw. 001, Kelurahan Bantarujeg, Kecamatan Bantarujeg, Kabupaten Majalengka, Jawa Barat. Sebidang tanah dan bangunan milik tergugat III yang terletak di Jl. Sinargalih No. 90, Rt. 001, Rw. 002, Kelurahan Sinargalih, Kecamatan Lemahsugih, Kabupaten Majalengka, Jawa Barat. Sebidang tanah dan bangunan milik tergugat IV yang terletak di Jl. Sudirman, Rt. 002, Rw. 001, Kelurahan Bantarujeg, Kecamatan Bantarujeg, Kabupaten Majalengka, Jawa Barat. Sebidang tanah dan bangunan milik Dadi Mulyadi (Sertipikat Hak Milik No.0060) yang terletak di Desa Gandu, Kecamatan Dawuan, Kabupaten Majalengka, Jawa Barat. "Putusan Mahkamah Agung Nomor 272/K/AG/2015 Tentang Pembiayaan Mudārabah."
} 
ini dapat dilaksanakan terlebih dahulu, meskipun ada upaya hukum perlawanan, banding maupun kasasi.

Kemudian pada tingkat banding atas permohonan tergugat atas putusan Pengadilan Agama Jakarta Selatan tersebut telah dibatalkan oleh Pengadilan Tinggi Agama Jakarta dengan putusan Nomor 5/Pdt.G/2014/PTA.JK tanggal 8 April 2014 menetapkan: (1). Menyatakan permohonan banding pembanding dapat diterima. (2). Membatalkan putusan Pengadilan Agama Jakarta Selatan Nomor 1695/Pdt.G/2012/PA.JS tanggal 31 Juli 2013. (3). Menyatakan Pengadilan Agama Jakarta Selatan tidak berwenang mengadili perkara tersebut. (4). Menyatakan sita jaminan yang dilakukan oleh Pengadilan Agama Jakarta Selatan melalui Pengadilan Agama Cirebon yang dituangkan dalam Berita Acara Sita Nomor 1695/Pdt.G/2012/ PA.JS tanggal 30 Mei 2013, Pengadilan Agama Kuningan dengan Berita Acara Sita Jaminan tanggal 20 Juni 2013 dan Pengadilan Agama Majalengka dengan Berita Acara Sita Jaminan tidak sah dan tidak berharga. (5). Memerintahkan Pengadilan Agama Jakarta Selatan untuk mengangkat sita jaminan tersebut.

Penggugat melakukan kasasi lewat Mahkamah Agung RI. Tanggal 18 Juni 2014. Mahkamah Agung menyatakan Pengadilan Tinggi Agama Jakarta telah salah menerapkan hukum dengan pertimbangan sebagai berikut: Pertama, berdasarkan fakta hukum dapat diketahui bahwa penggugat dan tergugat telah mengadakan dua kali akad, dan disepakati penyelesaian sengketa diajukan ke Basyarnas, dan muḍārib setuju jika șāhib al-mal (persero) memilih untuk mengajukan perkara ke Pengadilan Agama sesuai dengan kewenangannya.Kedua, berdasarkan ketentuan tersebut maka sesuai dengan Pasal 1344 KUHPerdata bahwa jika suatu kontrak diberi dua makna maka dipilih makna yang memungkinkan untuk dilaksanakan. ${ }^{27}$

Fakta hukum yang terdapat dalam persidangan terbukti tergugat telah wanprestasi atas perjanjian yang telah dibuat bersama, maka wajib untuk memenuhi prestasi kepada penggugat sesuai dengan ketentuan yang telah disepakati, karena itu putusan Pengadilan Tinggi Agama Jakarta harus dibatalkan dan Mahkamah Agung akan mengadili sendiri perkara ini dengan pertimbangan berikut ini: Setelah memeriksa dan mempelajari dengan seksama pertimbangan dan putusan Majelis Hakim Pengadilan Agama Jakarta Selatan, Mahkamah Agung berpendapat bahwa pertimbangan dan putusan Majelis Hakim Pengadilan Agama Jakarta Selatan tersebut telah tepat dan benar sehingga diambil alih sebagai pertimbangan dan putusan Mahkamah Agung sendiri.

Permohonan kasasi dari pemohon kasasi PT. Permodalan BMT Ventura tersebut. Membatalkan putusan Pengadilan Tinggi Agama Jakarta Nomor 5/Pdt.G/ 2014/PTA.JK tanggal 8 April 2014 yang membatalkan putusan Pengadilan Agama Jakarta Selatan Nomor 1695/Pdt.G/2012/PA JS tanggal 31 Juli 2013 dengan ketentuan: Pertama, mengabulkan gugatan penggugat untuk sebagian. Kedua, menyatakan sah akad pembiayaan mudārabah muqayyadah tanggal 1 Mei 2010 dan tanggal 3 Juli 2010 antara penggugat dan tergugat. Ketiga, Menyatakan bahwa tergugat tidak melaksanakan isi akad (inkar janji). Keempat, menghukum tergugat untuk membayar kepada penggugat uang sejumlah Rp1.426.846.507 (satu miliar empat ratus dua puluh enam juta delapan ratus empat puluh enam ribu lima ratus tujuh rupiah). Kelima, menyatakan sita jaminan yang dilaksanakan dengan berita acara sita tanggal 20 Juni 2013, dan tanggal 24 Juni 2013, sah dan berharga. ${ }^{28}$

\footnotetext{
27 "Putusan Mahkamah Agung Nomor 272/K/AG/2015 Tentang Pembiayaan Muḍāabah."

28 "Putusan Mahkamah Agung Nomor 272/K/AG/2015 Tentang Pembiayaan Muḍārabah."
} 


\section{Fungsi dan Tujuan Pembebanan Jaminan dalam Kontrak Pembiayaan Muḍārabah}

Prinsip bagi hasil merupakan karakteristik umum dan landasan dasar bagi operasional bank syariah secara keseluruhan, dan secara syariah kaidah ini dikenal dengan prinsip akad al-mudāarabah. ${ }^{29}$ Berdasarkan prinsip ini, bank syariah akan berfungsi sebagai mitra, baik dengan penabung maupun dengan pengusha yang meminjamkan dana lewat bank syariah. Bank syariah dengan penabung akan bertindak sebagai mudāarib (pengelola), sementara penabung akan bertindak sebagai pemilik modal. Modal yang dimaksud pada pembiayaan mudārabah harus berupa uang, dan tidak boleh berbentuk barang. ${ }^{30}$ Di sisi lain dengan pengusaha atau peminjam dana, bank syariah akan bertindak sebagai șāhib al-māl, baik dari tabungan, deposito, giro maupun dana bank sendiri. Sementara pengusaha atau peminjam akan berfungsi sebagai muḍarib (pengelola) karena melakukan usaha dengan cara memutar dan mengelola dana bank syariah. ${ }^{31}$

Berdasarkan kewenangan yang diberikan kepada mudārib, maka muḍārabah dibedakan menjadi dua macam yaitu mud̄ārabah muțlaqah artinya mudārib diberi kewenangan sepenuhnya untuk menentukan pilihan investasi yang dikehendaki oleh mud̄ārib. Kedua mud̄ārabah muqayyadah artinya arahan investasi ditentukan oleh pihak pertama sebagai pemilik modal dengan syarat-syaratyang telah ditetapkan oleh pemilik modal sedangkan mudārib sebagai pelaksana atau pengelola dana tersebut. Besarnya penentuan porsi bagi hasil antara kedua belah pihak disebutkan sesuai dengan adanya kerelaan ('an tarādin) dari masing-masing pihak. ${ }^{32}$ Penentuan bagi hasil hal yang perlu diperhatikan adalah tingkat risiko dalam kontrak pembiayaan mudārabah. Risiko dalam kontrak pembiayaan mud̄ārabah, terutama dalam hal penerapannya pada bank syariah relatif tinggi diantranya. Pertama, side streaming, yaitu jika nasabah menggunakan modal yang diberikan lewat kontrak pembiayaan mud̄ārabah tidak seperti yang disepakati dalam kontrak. Kedua, lalai dari kesalahan yang disengaja. Ketiga, penyembunyian keuntungan oleh nasabah bila nasabah tidak jujur. ${ }^{33}$

Untuk mengurangi kemungikan terjadinya risiko, bank syariah dapat menerapkan sejumlah batasan batasan dan syarat-syarat tertentu ketika menyalurkan pembiayaan mudāaabah, tujuannya agar muḍ̄arib secara sistematis dapat berprilaku memaksimalkan keuntungan bagi kedua belah pihak baik bagi mudārib maupun shahibul maal. Adapun batasan dan ketentuan yang harus diterapkan dapat dilakukan melalui: Pertama, penetapan jaminan berupa fixed asset atau lembaga penjamin. Pembebanan jaminan sesungguhnya dapat mencegah mudārib untuk melakukan penyelewengan dan penyalahgunaan modal yang diberikan oleh perbankan syariah, karena jaminan yang diberikan mudāarib kepada bank syariah sebagai shahibul maal dapat menghindari risiko yang timbul dari prilaku moral hazard mud̄ārib. Untuk mengurangi risiko tersebut sekema pembiayaan mud̄ärabah perlu ada a loan guarantee schema underwritten partly by the ghoverment and partly by the commercial banks, karena

\footnotetext{
29 Menurut pasal 1 angka 25 huruf a, danpasal 19 huruf c serta penjelasan umum Undang-Undang perbankan syariah No. 21 Tahun 2008 Tentang perbankan Syariah, dalam akad atau perjanjian bagi hasil ada dua macam akad atau perjanjian yaitu akad musyarakah ( join venture profit shariang) dan muḍārabah (trustee profit sharing), termasuk di dalamnya muḍarrabah mutlaqah dan mudāāabah muqayyadah.

30 Ibrāhīm Faḍil al-Dabū, Aqd Al-Muḍārabah: Dirasat Fi Al-Iqtishad Al-Islami (Amman: Ma’had al-'Ālamī fi Fiqh al-Islāmī, 1997), 7071.

31 Muhammad Ghafur Wibowo, Potret Perbankan Syariah Indonesia Terkini : Kajian Kritis Perkembangan Perbankan Syariah (Yogyakarta: Biruni Press, 2007), 76.

32 Renny Supriyatni Bachro, Peran Bank Syariah Dalam Pembangunan Ekonomi Idnonesia (Bandung: Books Terrace nad Library, 2013), 145.

33 M. Nur Yasin, Hukum Ekonomi Islam: Geliat Perbankan Syariah Di Indonesia (Malang: Universitas Islam Negeri Malang Press, 2009), 196.
} 
untuk menghubungkan sektor riil dengan sektor keuangan malalui pembiayaan mudharbah perlu ada lembaga penjamin..$^{34}$

Eksistensi jaminan sangat menentukan kemampuan bank syariah dalam menggerakkan sektor riil melalui alokasi skim pembiayaan mud̄ārabah. Pembebanan jaminan pada pembiayaan mud̄ārabah dapat mengukur perilaku mitra usaha sehingga dapat dipercaya akan amanah dalam mengelola dana yang diberikan, dan kemampuan muḍ̄arib dalam berusaha. Jika perilaku amanah dari mudārib masih diragukan dan kualitas kemampuan mudārib untuk mengelola usaha rendah, maka bank syariah akan meminta jaminan untuk menghindari risiko yang akan ditimbukan oleh mudārib. Ketika kualitas mudārib rendah dalam hal mengelola usaha, maka perlu ada lembaga yang dapat memberikan pelatihan sehingga muḍ̄arib yang memenuhi syarat untuk memperoleh pembiayaan dari bank syariah dan dijamin oleh lembaga tersebut. Adanya lembaga jaminan yang menjamin mudārib, bank syariah akan memperoleh kembali dana yang telah diberikan jika terjadi kegagalan mudārib karena negligence (kelalaian) ataupun moral failure, tetapi jika kegagalan usaha mudārib karena normal bussiness loss, maka bank syariah turut serta menanggung risiko dan kerugian tersebut. ${ }^{35}$

Hukum Islam memandang bahwa pembiayaan mudāarabah prinsipnya berdasarkan amanah dan wakālah. Ketika muḍārib sebagai al-amīn maka muḍ̄arib adalah orang yang dapat dipercaya oleh shahibul maal. Sedangkan dalan konsep wakālah maka mud̄ārib adalah sebagai wakil sekaligus pengelola usaha yang dibiayai oleh bank syariah. Modal yang diberikan oleh shahibul maal merupakan amanah karena itu menerima dan mengelola dana yang diberikan haruslah seizin dari șāhib al-māl. Untuk itu mudārib tidak menanggung risiko yang terjadi apabila terjadi kerugian terkecuali risiko tersebut disebabkan pada kasus penyelewengan, keteledoran, dan unsur kesengajaan yang dilakukan oleh mudārib. Ketika muḍ̄arib sebagai wakil dari șāhib al-māl untuk mengelola dan mengembangkan dalam bentuk usaha, konsekuensinya adalah șāhib al-māl tidak dapat menuntut adanya jaminan serta ketentua-ketentuaan lainnya dari mud̄ārib. Menurut fukaha Malikiya dan Syafi'iyah jika șāhib al-māl menuntut adanya jaminan maka kontrak tersebut tidak sah. Sedangkan menurut fukaha Hanafiyah dan Hanabilah walaupun kontrak mudārbah dapat dibenarkan tetapi syaratnya menjadi bathal. ${ }^{36}$

Untuk saat ini perbankan syariah sulit untuk menentukan karakter dan sifat dari setiap mud̄ārib. Sehingga, banyak kasus penyelewengan dan penipuan baik secara kualitas maupun kuantitas. Selain itu dana yang dimiliki oleh bank syariah tidaklah sepenuhnya milik bank syariah melainkan merupakan milik pihak ketiga yang dititipkan lewat tabungan dan deposito dalam bentuk wadi'ah. Oleh karena dana tesebut merupakan titipan dari pihak katiga, maka prinsip yang harus dipegang adalah tidak boleh saling membahayakan.

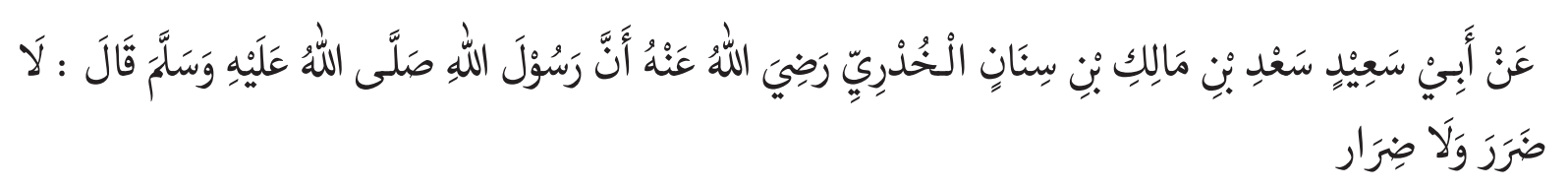

\footnotetext{
34 Abdullah Saeed, Bank Islam Dan Bunga Bank, Studi Kritis Dan Interpretasi Kontemporer Tentang Riba Dan Bunga (Yogyakarta: Pustaka Pelajar, 2003), 103.

35 Wahbah al-Zuhailī, Naz̄ariyyah Al-Ḍamān Wa Al-Aḥkām Al-Mas'ūliyyah Al-Māddaniyyah Wa Al-Jina’iyyah Fi Al-Fiqh Al-Islāmì (Damaskus: Dar al-fikr al-Mu`ashir, 1998), 159; Abdul Razāk Rāḥim Jiddī al Haytī, Al-Mașārif Al-Islāmiyyah Bayn Al-Nazariyyah Wa Al-Tațiiq (Amman: Dar Usamah li al-Nasyr wa al-Tawzi', 1998), 493.

36 Ibnu Rusyd, Bidāyah Al-Mujtahid Wa Nihāyah Al-Muqtașid, (Jeddah: Makatabah al-Ḥaramain, 1994), II/179; Wahbah al-Zuhaylī, Al-Fiqh Al-Islāmī Wa Adillatuh (Bayrūt: Dār al-Fikr, 1985), 3945.
} 
Dari Ibn Abbas r.a. Bahwa Rasululloh saw. Bersabda. "Tidak boleh membahayakan orang lain dan tidak boleh membalas tindakan orang lain yang membahayakan dengan bahaya pula". (H.R. Ahmad dan Ibn Majah).

Pembebanan jaminan dalam kontrak pembiayaan mudārabah dilakukan demi untuk keamanan modal yang diberikan oleh bank syariah melalui pihak ketiga. Pertimbangan inilah yang membolehkan bagi bank syariah untuk meminta jaminan dari mudāarib, karena jaminan tersebut telah menjadi kebutuhan (hājjah) bagi terlaksananya kontrak pembiayaan mud̦ārabah. Tetapi perlu dipahami bahwa jaminan tersebut tidaklah mutlak melainkan fleksibel, mudah, dan tidak menyulitkan bagi mudārib. Artinya jaminan yang dimaksud tidak diharuskan berbentuk material tetapi dapat dalam bentuk moril yaitu surat rekomendasi dari seseorang atau lembaga yang dapat dijadikan penjamin, terpercaya dan bertanggung jawab sebagaimana dalam bentuk materil (barang). ${ }^{37}$

Kedua bentuk jaminan tersebut terdiri dari jaminan kebendaan dan perorangan atau rahn dan kafālah dapat dijadikan sebagai pegangan ketika timbul permasalahan yang timbul dari pembiayaan muḍārabah yang tidak diinginkan oleh kedua pihak. Pembebanan jaminan dari muḍārib dalam pembiayaan mud̄ārabah dapat dibenarkan dan dibolehkan berpijak kepada kaidah teori hukum Islam yaitu teori al-mașlahah yang mengacu kepada prinsip kebutuhan, kepentingan, kebaikan dan masalah umum selma tidak bertentangan dengan prinsip dan dalil yang tegas dari syar'i, dan benar-benar membawa kepada kebaikan bersama yang tidak berdampak menyulitkan serta merugikan pihak lain secara umum. Ketiga, Menetapkan rasio maksimal biaya operasi terhadap pendapatan operasi, hal ini dimaksudkan agar muḍārib menjalankan operasional bisninsnya secara efesien. ${ }^{38}$

Untuk memastikan mud̄ārib menjalankan bisnisnya melalui kontrak pembiayaan mud̄ārabah dengan efesien, maka dapat ditetapkan syarat agar mudārib harus selalu menjaga rasio maksimal misalnya 80\%. Komitmen untuk menetapkan prinsip profit and loss sharing pada kontrak pembiayaan mudārabah, perbankan syariah sebenarnya dalam hal ini berperan sebagai șāhib al-māl. Sedangkan moral hazard yang dikahwatirkan selama ini melekat pada mud̄ārib penerima pembiayaan mudārabah dapat dikurangi dengan menyepakati terlebih dahulu biaya-biaya apa saja yang lazimnya ada pada waktu suatu usaha tertentu yang dikelola oleh mudārib. Pada akad pertama kemungkinan akan ada biaya penting yang luput dicantumkan dalam kesepakatan, namun akad berikutnya biaya yang luput akan dapat berkurang sehingga pada akhirnya akan ditemukan standar biaya yang berlaku untuk suatu usaha yang dikelola oleh mudārib. ${ }^{39}$

\section{Pengikatan Jaminan dalam Kontrak Pembiayaan Muḍārabah}

Penerapan kontrak pembiayaan mudārabah selalu terkait dengan pembebanan jaminan. Hal ini dilakukanolehbanksyariahuntukmendapatkankepasatianbahwapembiayaanyangdiberikanmelalui pembiayaan mudāabah dapat dipergunakan sesuai dengan kebutuhan. Sehingga dengan adanya pembebanan jaminan dalam bentuk perjanjian akan dapat mengurangi risiko debitur wanprestasi yang mungkin terjadi apabila penerima pembiayaan muḍārabah tidak dapat mengembalikan modal yang diberikan oleh bank syariah. Pembebanan jaminan pada bank syariah berdasarkan kepada pasal

37 A Chairul Hadi, "Problematika Pembiayaan Mudharabah Di Perbankan Syariah Di Indonesia," Al-Iqtishad 3, no. November 2010 (2011): 193-208, https://doi.org/10.15408/aiq.v3i2.2521.

38 Hadi.

39 Hadi. 
23 ayat (1) dan (2) Undang-undang Nomor 21 Tahun 2008 Tentang Perbankan Syariah, dan 8 Undangundang nomor 10 Tahun 1998 Tentang Perbankan. Bahwa bank syariah dan UUS harus mempunyai keyakinan atas kemauan dan kemmapuan mudārib untuk melunasi seluruh kewajibannya tepat pada waktunya. Hal ini berarti bank syariah wajib mempunyai keyakinan berdasarkan analisis yang mendalam itikad baik dan kemampuan nasabah untuk melunasi kewajibannya sesuai dengan perjanjian. ${ }^{40}$

Terlepas dari permasalahan jaminan yang diterapkan pada bank syariah, baik jaminan pokok dan jaminan tambahan berdasarkan putusan Mahkamah Agung Nomor 272/K/AG/20215 bahwa pembebabanan jaminan hak tanggungan dengan sertifikat hak milik dalam kontrak pembiayaan mudārabah adalah sah dan sesuai prinsip perbankan syariah. Untuk itu ketika pelaku usaha melakukan wanprestasi atas kontrak yang telah disepakati maka jaminan dapat dijadikan sebagai ganti rugi yang dialamai oleh pemberi modal dalam hal ini bank syariah melalui sita jaminan yang dilaksanakan dengan berita acara sita sah dan berharga. Posisi ini pada prinsipnya ketika pelaku usaha wanprestasi dengan sendirinya bank syariah dapat mengalihkan objek yang menjadi jaminan. Karena bank telah melakukan pemberitahuan melalui somasi selama tiga kali atas wanprestasinya pelaku usaha. Tetapi untuk mendapatkan legalitas dan kepastian hukum, bank syariah melakukan upaya hukum bahwa objek jaminan yang diberikan pelaku usaha dapat dialihkan untuk melunasi kerugian sehingga kekuatan hukum dan duduk perkaranya menjadi mengikat.

Berdasarkan putusan Mahkamah Agung yang membatalkan putusan Pengadilan Tinggi Agama Jakarta Nomor 5/Pdt.G/ 2014/PTA, setidaknya ada tiga argumentasi hukum yang dapat disampaikan. Pertama, pembebanan jaminan dalam kontrak pembiayaana mudārabah dapat diterapkan dengan tujuan untuk menghindari wanprestasi yang dilakukan oleh debitur. Kedua, sita terhadap objek jaminan dalam hal ini jaminan kebendaan dalam bentuk hak tanggungan dengan sertifikat hak milik sah, artinya ketika debitur wanprestasi maka pelaku usaha dapat mengalihkan objek jaminan tersebut. Ketiga, segala bentuk kerugian dalam kontrak pembiayaan mudārabah atas dasar kesalahan yang dilakukan maka kerugian ditanggung sepenuhnya oleh debitur. Mahkamah Agung menyatakan Pengadilan Tinggi Agama Jakarta telah salah menerapkan hukum dengan pertimbangan sebagai berikut: Pertama, berdasarkan fakta hukum dapat diketahui bahwa penggugat dan tergugat telah mengadakan dua kali akad, dan ketaika terjadi sengketa disepakati penyelesaian sengketa diajukan Pengadilan Agama sesuai dengan kewenangannya. Kedua, berdasarkan ketentuan tersebut maka sesuai dengan Pasal 1344 KUHPerdata bahwa jika suatu kontrak telah disepakati maka berlaku baginya asas mengikat layaknya undang undang (pacta sunt servanda).

Ketentuan pasal 23 ayat (1) dan (2) Undang-undang Perbankan Syariah beserta penjelasannya, diperkuat lagi dengan pasal 8 Undang-undang perbankan dan penjelasan, bahwa berdasarkan analisis yang mendalam atas itikad dan kemampuan serta kesanggupan nasabah mud̄ōrib untuk melunasi kewajibannya yakni mengembalikan pembiayaan yang dimaksud sesuai dengan perjanjian itulah yang diartikan sebagai jaminan pembiayaan, termasuk pembiayaan muḍārabah. Pada ayat (2) dalam

\footnotetext{
40 Pasal 23 ayat (1) menegaskan Bank Syariah dan /atau UUS harus mempunyai keyakinan atas kemauan dan kemampuan calon nasabah penerima fasilitas untuk melunasi seluruh kewajiban pada waktunya, sebelum Bank Syariah dan /atau UUS menyalurkan dana kepada nasabah Penerima Fasilitas. Ayat (2) Untuk memperoleh keyakian sebagaimana dimaksud pada ayat (1), Bank Syariah dan/atau UU wajib melakkan penilaian yang seksama terhadap watak, kemampuan, modal, agunan, dan prospek usaha dari calon nasabah penerima fasilitas.Lebih lanjut dapat dilihat Dalam Undang-undang Nomor 1 Tahun 2008 Tentang Perbankan Syariah pasal 23 ayat (1) dan (2) beserta penjelsannya.
} 
hal melakukan analisis terhadap watak, kemampuan, modal, agunan, dan prospek usaha dari mudārib, dapat disimpulkan bahwa jaminan hanya merupakan salah satu unsur dari pembiayaan mudārabah, bahkan dijelaskan jika berdasarkan unsur-unsur lain bank syariah telah memperoleh keyakinan atas kemampuan mudārib untuk mengembalikan utangnya, agunan yang diserahkan dapat hanya berupa barang, proyek atau hak tagih yang dibiayai dengan pembiayaan mud̄ārabah yang bersangkutan.

Perspektif perbankan, pemberian pembiayaan mudārabah oleh bank syariah mengandung risiko, oleh karena itu ketika bank syariah memberikan pembiayaan mudārabah harus memperhatikan azasazas pembiayaan yang sehat yaitu mengedepankan prisnip kehati-hatian dan prinsip risiko. Adapun bentuk pelaksanaan asas perinsip kehati-hatian dan prinsip risiko dilakukan dengan cara meminta jaminan dalam pengertian keyakinan akan kemampuan nasabah mud̄arib sesuai dengan pesyaratan yang telah ditentukan merupakan faktor penting yang harus diperhatikan oleh bank termasuk bank syariah. ${ }^{41}$ Untuk memperoleh keyakinan terhadap nasabah bank syariah dapat dilakukan dengan penilaian terhadap watak, kemampuan, modal, agunan, dan prospek usaha nasabah dan itikad baik (willingness to pay) dan kemampuan membayar (ability to pay) untuk melunasi kembali pinjaman yang diberikan oleh bank. ${ }^{42}$ Mengingat jaminan merupakan salah satu unsur yang harus dinilai dalam hal pemberian pembiayaan mudārabah, sehingga apabila penilaian berdasarkan terhadap faktor lainnya bank telah memperoleh keyakinan akan kemampuan nasabah mudārib untuk memenuhi kewajibannya, bank tidak menganggap perlu meminta jaminan harta sebagai jaminan tambahan yang tidak berkaiatan langsung dengan objek atau proyek yang dibiayai melalui fasilitas pembiayaan mudāarabah. ${ }^{43}$

Sudut pandang hukum jaminan sebagaimana tercantum dalam Undang-undang No. 21 Tahun 2008 Tentang Perbankan Syariah, pengertian jaminan yang digunakan dan praktik perbankan lebih menitik beratkan pada aspek sosial ekonomi, karena itu istilah agunan sebagaimana dirumuskan dalam Undang-undang No. 10 Tahun 1998 adalah jaminan tambahan yang diserahkan nasabah mud̄ārib kepada bank dalam rangka pemberian fasilitas pembiayaan muḍārabah. Sesungguhnya tujuan pengikatan jaminan dalam kontrak pembiayaan mudārabah merupakan bagian dari pelaksanaan prinsip-kehati-hatian dan prissip risiko seperti yang diamanahkan pasal 35 ayat (1) Undang-undang No. 21 tahun 2008 Tentang perbankan syariah, ${ }^{44}$ sehingga bank syariah dapat mengantisipasi kemungkinan terjadinya kegagalan usaha dari proyek mudārib yang dibiayai oleh bank syariah atau untuk menghindari mudārib wanprestasi ${ }^{45}$ Selain itu pengikatan jaminan pada pembiayaan mudārabah untuk mendorong mudārib agar mau bersungguh sungguh dalam melaksanakan usaha dan mengelola proyek yang dibiayai oleh bank syariah, sehingga ketika mudārib lalai dan bermainmain atas modal yang diberikan, dan jaminan dapat dijadikan sebagai pengganti pembayaran modal yang diberikan kepada muḍārib. ${ }^{46}$

${ }_{41}$ Indrawati Soewarso, Aspek Hukum Jaminan Kredit (Jakarta: Institut Bankir Indonesia, 2002), 8.

42 Ifa Latifa Fitriani, "Jaminan Dan Agunan Dalam Pembiayaan Bank Syariah Dan Kredit Bank Konvensional," Jurnal Hukum Dan Pembangunan 47, no. 1 (2017): 134-49, https://doi.org/http://dx.doi.org/10.21143/jhp.vol47.no1.138.

43 Undang-undang Nomor 8 Tahun 2008 Tentang Perbankan Syariah Pasal 23 ayat (1 dan 2) beserta penjelasannya. Penjelasan ini juga senada dengan penjelasan pasal 8 Undang-undang Nomor 10 tahun 1998 Tentang Perbankan.

44 Bank Syaraiah dan UUS dalam melakukan kegiatan usahanya wajib menerapkan prinsip kehati-hatian. Dalam rangka menjaminterlaksananya pengambilan keputusan dalam pengelolaan bank yang sesuai dengan prinsip kehati-hatian, bank memiliki dan menerapkan, antara lain sistem pengawan interen. Pasal 35 ayat (1) dan penjelasannya. Undang-undang Nomor 21 Tahun 2008 Tentang Perbankan Syariah.

45 Senada dengan undang-undang perbanakn syariah, pasal 1131 KUHPerdata juga mengungkapkan bahwa fungsi jaminan ditujukan dalam upaya pemenuhan kewajiban nasabah untuk melakukan pembayaran, karena itu jaminan dapat memberikan hak kepada bank untuk mengambil pelunasan dari hasil penjualan harta kekayaan yang menjadi objek jaminan.

46 Lukman Dendawijaya, Manajemen Perbankan (Jakarta: Ghalia Indonesia Anggota IKAPI, 2005), 92. 
Menurut Rahman Ghazali, tujuan utama dari pengikatan jaminan disetip pembiayaan dan utang piutang pada hakikatnya untuk memberikan kenyamanan dan kemanan bagi semua orang yang melakukan transaksi, karena itu keberadaan jaminan tidak dapat dihindari. Untuk saat ini jaminan dapat dijadikan tolak ukur sejauh mana nasabah mudārib bersungguh sungguh dengan usaha yang keras untuk mengembalikan modal dan untung yang disepakati dalam perjanjian, terlebih ketika modal tersebut berasal dari perbankan syariah di mana modal tersebut tidak sepenuhnya milik bank syariah. ${ }^{47}$ Wahbah mempersentasikan bahwa fungsi utama dari jaminan dapat dilihat dari sudut hikmah tasry' dari jaminan yaitu untuk memperkuat hak seseorang yaitu mempermudah transaksi dalam pembayaran lalu lintas utang piutang, pinjam meminjam dan dalam bentuk pembiayaan. Sehingga orang yang memiliki hak mendapatkan ketenangan terhadap transaksi utang yang dipinjamkan kepada orang lain stau benda yang dipinjamkan. ${ }^{48}$

Benda yang dijadikan sebagai jaminan dalam konrak pembiayaan muḍarabah dinilai dapat mengcover pengembalain modal dan bagi hasil, sehingga pemilik modal merasa yakin bahwa modal yang disalurkan dapat dilindungi. Ketika pelaku usaha tidak dapat mengembalikan modal karena faktor kelalaian dan menyalahi kontrak pembiayaan mudārabah, maka pemilik modal memiliki hak untuk mengeksekusi barang jaminan dengan cara menjual untuk menunaikan kewajiban pelaku usaha. Selian itu dengan adanya jaminan hal ini akan dapat memperkecil sengketa pembiayaan mud̄ārabah pada bank syariah. ${ }^{49}$ Praktiknya jaminan yang diberikan oleh nasabah muḍārib diikat dalam bentuk perjanjian, bahwa apabila nasabah mud̄ārib tidak dapat membayar seluruh kewajibannya dan bagi hasil yang disepakati, bank berhak mengambil sebagian atau seluruh hasil dari penjualan harta jaminan tersebut sebagai bentuk pelunasan kewajiban nasabah mudārib kepada bank syariah. ${ }^{50}$

Pengikatan jaminan selain sebagai pengaman ketika mudārib tidak memenuhi kewajibannya, jaminan yang diberikan dapat dijual dan selanjutnya dipergunakan sebagai sumber pelunasan pembiayaan krediat atau pembiayaan berdasarkan prinsip Syariah. Keberadaan jaminan dalam kontrak pembiayaan mudārabah dapat memperkecil risiko dan merupakan sebagai upaya penyelesaian sengketa ketika debitur wanprestasi, karena apabila mud̄ōrib menyalahi perjanjian dan lalai dari tanggung jawabnya sebagai mudārib, barang jaminan dapat dijual sebagai sumber pelunasan modal yang diberikan oleh bank syariah. ${ }^{51}$ Jika dipahami secara holistik dan komprehensif fungsi jaminan pembiayaan berupa watak, kemampuan dan prospek usaha yang dimiliki oleh debitur merupakan jaminan immateril berfungsi sebagai first way out, ketika nasabah mengalami kegagalan pembiayaan syariah (wanprestasi) atau terjadi pembiayaan bermasalah maka second way out sebagai jaminan hak tanggungan, bank dapat menjual benda jaminan yang dibebanai dengan hak tanggungan sekaligus sumber pelunasan atas pembiayaan yang diberikan. ${ }^{52}$

Penjelasan tentang pengikatan jaminan sebagaimana dijelaskan di atas, menggambarkan suatu prinsip yang tidak membenarkan bank mengambil barang jaminan tersebut secara langsung untuk dimiliki dan dianggap sebagai pelunasan pembiayaan mudārabah yang telah diberikan. Perbuatan

\footnotetext{
47 Abdur Rahman Ghazaly, Fiqh Munakahat (Jakarta: Kencana, 2006), 210.

48 Wahbah al-Zuhaylī, Al-Fiqh Al-Islāmī Wa Adillatuh (Beirūt: Dār al-Fikr, 1985), IV/4143.

49 Gatot Supramono, Transaksi Bisnis Saham Dan Penyelesaian Sengketa Melalui Pengadilan (Jakarta: Kencana Prenada Media, 2014), 50.

50 Arus Akbar and Wirawan B. Ilyas, Pokok-Pokok Hukum Bisnis (Jakarta: Salemba Empat, 2013), 79.

51 R. Tjiptoadinugroho, Perbankan Masalah Perkreditan: Penghayatan, Analisis Dan Penuntun (Jakarta: Pradnya Paramita, 1990$), 44$.

52 Sawitri Putri Nursakti, "Jaminan Hak Tanggungan Pada Produk Pembiayaan Murabahah Dan Musyarakah Di Bank Muamalat Indonesia," DiH Jurnal Ilmu Hukum 14, no. 1 (2018): 81-98, https://doi.org/10.5281/zenodo.1188360.81.
} 
demikian yang mengambil langsung barang jaminan untuk dimiliki, menurut undang-undang batal demi hukum. Terkait dengan prinsip bahwa kebendaan seseorang yang menjadi jaminan bagi para kreditur secara bersama-sama, dan hasil dari penjualan dibagi menurut keseimbangan. Kreditur berhak atas sebagian hasil penjualan dalam hal terdapat lebih dari satu orang kreditur, tetapi jika kreditur hanya satu orang maka kreditur tersebut berhak atas seluruh hasil dari penjualan barang jaminan dengan ketentuan bahwa hak tagihnya sama atau lebih besar dari hasil penjualan. Penjualan barang jaminan pada dasarnya dilakukan melalui penjualan umum dengan cara lelang, kecuali untuk barang jaminan gadai dapat diperjanjikan melakukan penjualan di bawah tangan. Uraian di atas, bentuk jaminan umum yang diatur dalam pasal 1131 KUHperdata tidak memberikan kedudukan yang kuat dan aman bagi kreditur, karena itu perlu diupayakan agar pembebanan jaminan dilakukan dengan cara memberikan kedudukan yang kuat kepada kreditur..$^{33}$

Terkait dengan putusan Mahkamah Agung Nomor 272/K/AG/2015 penulis menyimpulkan, pengikatan jaminan dalam kontrak pembiayaan muḍ̄abah baik dalam hukum Islam maupun hukum positif dapat dijadikan sebagai upaya mengantisipasi penyelesaian sengketa debitur wanprestasi, karena itu pengikatan jmainan bertujuan untuk: (a). Memberikan dorongan kepada mudārib untuk memenuhi janjinya, khususnya mengenai pembayaran kembali sesuai dengan syarat-syarat yang ditetapkan dalam kontrak pembiayaan muḍārabah. (b). Sebagai pengaman, artinya apabila mudārib tidak memenuhi kewajibannya, maka jaminan yang diberikan dapat dijual dan dipergunakan sebagai sumber pelunasan dalam kontrak pembiayaan mudārabah. (c). Pemilik modal dalam hal ini bank syariah tidak kehilangan modal yang diberikan, Karena modal tersebut bukanlah merupakan milik bank syariah melainkan milik nasabah yang menitipkan dananya pada bank syariah.(d). Memperkecil risiko, artinya ketika mudārib lalai dan menyalahi kontrak, maka jaminan dapat dijadikan sebagai upaya meminimalisir risiko. (e). Adanya kepastian hukum pihak bank bahwa pembiayaan mudāarabah yang diberikan akan kembali dengan cara mengeksekusi objek jaminan..$^{54}$

\section{Penutup}

Setidaknya ada tiga tujuan penerapan pembebanan jaminan dalam kontrak pembiayaan mudārabah. Pertama, untuk menerapkan prinsip kehati-hatian dan prinsip risiko. Secara umum ada dua bentuk risiko dalam kontrak pembiayaan mudārabah yaitu default risk (risiko gagal bayar) dan recovery risk (risiko jaminan). Hal ini dilakukan untuk menjalankan amanat pasal 35 dan 39 Undang-undang No. 21 Tahun 2008 Tentang Perbankan Syariah. Kedua sebagai mitigasi untuk memperkecil risiko kerugian ketika debitur wanprestasi atas perjanjian yang disepakati sehingga dapat memanimalisir penyelesaian sengketa pembiayaan mudārabah. Ketiga, pembebanan jaminan dapat dijadikan sebagai upaya untuk memperkecil kasus-kasus penyelesaian sengketa pembiayaan muḍārabah sehingga dapat dijadikan sebagai jalan terkahir untuk mengantisipasi penyeleaian sengketa debitur wanprestasi. Perlu dipahami bahwa dasar filosofi pengikatan jmainan dalam kontrak pembiayaan mudārabah pada prinsipnya untuk menghindari adanya moral hazard dari pihak debitur yang lalai atau menyalahi kontrak yaitu: Ta'addi (melakukan sesuatu yang tidak boleh/tidak semestinya dilakukan), Taqșir (tidak melakukan sesuatu yang boleh/semestinya dilakukan), Mukhālafah al-syurūt, melanggar ketentuan-ketentuan (yang disepakati pihak-pihak yang berakad). Jaminan tersebut hanya dapat

53 Soewarso, Aspek Hukum Jaminan Kredit, 14.

54 Saeed, Bank Islam Dan Bunga Bank, Studi Kritis Dan Interpretasi Kontemporer Tentang Riba Dan Bunga, 136. 
dieksekusi jika kerugian dalam kontrak pembiayaan mudārabah disebabkan oleh character risk dari debitur. Uuntuk menghindari character risk dari mudāarib , maka perlu pembebanan jaminan dalam kontrak pembiayaan mud̄ārabah.

\section{DAFTAR PUSTAKA}

Abdur Rahman Ghazaly. Fiqh Munakahat. Jakarta: Kencana, 2006.

Admin. "Direktori Putusan - Mahkamah Agung," n.d. https://putusan3.mahkamahagung.go.id/.

Bachro, Renny Supriyatni. Peran Bank Syariah Dalam Pembangunan Ekonomi Idnonesia. Bandung: Books Terrace nad Library, 2013.

Dendawijaya, Lukman. Manajemen Perbankan. Jakarta: Ghalia Indonesia Anggota IKAPI, 2005.

Fitriani, Ifa Latifa. "Jaminan Dan Agunan Dalam Pembiayaan Bank Syariah Dan Kredit Bank Konvensional." Jurnal Hukum Dan Pembangunan 47, no. 1 (2017): 134-49. https://doi.org/http:// dx.doi.org/10.21143/jhp.vol47.no1.138.

H.S., Salim. Hukum Kontrak : Teori Dan Teknik Penyusunan Kontrak. Jakarta: Sinar Grafika, 2006.

Hadi, A Chairul. "Problematika Pembiayaan Mudharabah Di Perbankan Syariah Di Indonesia." ALIqtishad 3, no. November 2010 (2011): 193-208. https://doi.org/10.15408/aiq.v3i2.2521.

Hasbullah, Ny. Hj. Frieda Husni. Hukum Kebendaan Perdata: Hak-Hak Yang Memberi Jaminan. Jakarta: Ind.Hill Co, 2002.

Haytī, Abdul Razāk Rāḥim Jiddī al. Al-Mașārif Al-Islāmiyyah Bayn Al-Nazariyyah Wa Al-Tațbìq. Amman: Dar Usamah li al-Nasyr wa al-Tawzi', 1998.

Hejazziey, Djawahir. Hukum Perbankan Syariah. Yogyakarta: Deepublish, 2013.

Ibrāhīm Faḍ̄l al-Dabū. Aqd Al-Muḍārabah: Dirasat Fi Al-Iqtishad Al-Islami. Amman: Ma'had al-'Ālamī fi Fiqh al-Islāmī, 1997.

Ilyas, Arus Akbar and Wirawan B. Pokok-Pokok Hukum Bisnis. Jakarta: Salemba Empat, 2013.

Jeni Susyanti. Pengelola Lembaga Keuangan Syariah. Pekabbaru: Empat Dua, 2016.

Nasroen Yasabri, Nina Kurnia Dewi. Penjaminan Kredit: Mengantar UKMK Mengakses Pembiayaan. Bandung: Alumni, 2008.

Nursakti, Sawitri Putri. "Jaminan Hak Tanggungan Pada Produk Pembiayaan Murabahah Dan Musyarakah Di Bank Muamalat Indonesia.” DiH Jurnal Ilmu Hukum 14, no. 1 (2018): 81-98. https://doi.org/10.5281/zenodo.1188360.81.

“Putusan Mahkamah Agung Nomor 272/K/AG/2015 Tentang Pembiayaan Muḍārabah," 2015.

Rusyd, Ibnu. Bidāyah Al-Mujtahid Wa Nihāyah Al-Muqtașid,. Jeddah: Makatabah al-Ḥaramain, 1994.

Saeed, Abdullah. Bank Islam Dan Bunga Bank, Studi Kritis Dan Interpretasi Kontemporer Tentang Riba Dan Bunga. Yogyakarta: Pustaka Pelajar, 2003.

Satrio, J. Hukum Jaminan, Hak-Hak Jaminan Pribadi Penanggungan (Borgtocht) Dan Perikatan Tanggung Menanggung. Bandung: Cipta Aditya Bakti, 1996.

Soewarso, Indrawati. Aspek Hukum Jaminan Kredit. Jakarta: Institut Bankir Indonesia, 2002. 
Sofwan, Sri Soedewi Masjchoen. Hukum Jaminan Di Indonesia, Pokok-Pokok Hukum Jaminan Dan Jaminan Perorangan. Yogyakarta: Liberty, 1980.

Subekti. Kitab Undang-Undang Hukum Perdata. Jakarta: Pradnya Paramita, 2006.

-_-. Pokok-Pokok Hukum Perdata. Jakarta: Intermasa, 2005.

Supramono, Gatot. Transaksi Bisnis Saham Dan Penyelesaian Sengketa Melalui Pengadilan. Jakarta: Kencana Prenada Media, 2014.

Suyatno, Thomas. Dasar-Dasar Perkreditan. Jakarta: Gramedia, 1988.

Tjiptoadinugroho, R. Perbankan Masalah Perkreditan: Penghayatan, Analisis Dan Penuntun. Jakarta: Pradnya Paramita, 1990.

Undang-undang Nomor 10 Tahun 1998 Tentang Perbankan (1998).

Undang-undang Nomor 21 Tahun 2008 Tentang Perbankan Syariah (2008).

Wahbah al-Zuhailī. Naz̄ariyyah Al-Ḍamān Wa Al-Aḥkām Al-Mas'ūliyyah Al-Māddaniyyah Wa Al-Jina'iyyah Fi Al-Fiqh Al-Islāmī. Damaskus: Dar al-fikr al-Mu`ashir, 1998.

Wahbah al-Zuhaylī. Al-Figh Al-Islāmī Wa Adillatuh. Bayrūt: Dār al-Fikr, 1985.

Wibowo, Muhammad Ghafur. Potret Perbankan Syariah Indonesia Terkini : Kajian Kritis Perkembangan Perbankan Syariah. Yogyakarta: Biruni Press, 2007.

Wijaja, Gunawan. Seri Hukum Bisnis Memahami Prinsip Keterbukaan Dalam Hukum Perdata. Jakarta: Rajawali Press, 2006.

Yasin, M. Nur. Hukum Ekonomi Islam: Geliat Perbankan Syariah Di Indonesia. Malang: Universitas Islam Negeri Malang Press, 2009. 
